"Capital regulations, supervision and the international harmonization of bank capital ratios"

\begin{tabular}{|c|c|}
\hline AUTHORS & Kevin T. Jacques \\
\hline ARTICLE INFO & $\begin{array}{l}\text { Kevin T. Jacques (2017). Capital regulations, supervision and the international } \\
\text { harmonization of bank capital ratios. Banks and Bank Systems, 12(1-1), 175-183. } \\
\text { doi:10.21511/bbs.12(1-1).2017.11 }\end{array}$ \\
\hline DOI & http://dx.doi.org/10.21511/bbs.12(1-1).2017.11 \\
\hline RELEASED ON & Monday, 19 June 2017 \\
\hline RECEIVED ON & Monday, 30 January 2017 \\
\hline \multirow[t]{2}{*}{ ACCEPTED ON } & Thursday, 09 March 2017 \\
\hline & $(c c)$ BY-NC \\
\hline LICENSE & $\begin{array}{l}\text { This work is licensed under a Creative Commons Attribution-NonCommercial } 4.0 \\
\text { International License }\end{array}$ \\
\hline JOURNAL & "Banks and Bank Systems" \\
\hline ISSN PRINT & $1816-7403$ \\
\hline ISSN ONLINE & $1991-7074$ \\
\hline PUBLISHER & LLC "Consulting Publishing Company "Business Perspectives" \\
\hline FOUNDER & LLC "Consulting Publishing Company "Business Perspectives" \\
\hline & $\begin{array}{l}\text { ニ-: } \\
\text { =-: }\end{array}$ \\
\hline NUMBER OF REFERENCES & NUMBER OF FIGURES \\
\hline 38 & 0 \\
\hline
\end{tabular}

(C) The author(s) 2022. This publication is an open access article. 
Kevin T. Jacques (USA)

\title{
Capital regulations, supervision and the international harmonization of bank capital ratios
}

\begin{abstract}
In recent decades, despite the Basel Committee's effort to develop internationally uniform regulatory capital standards, the capital ratios of banks across countries continue to exhibit significant differences. This paper examines the fundamental question of whether, given a uniform regulatory capital standard, regulators should expect similar banks to exhibit similar risk-based capital ratios. More specifically, this study develops a one-period theoretical model to examine the level playing field argument in light of not only uniform regulatory capital standards but also differences in bank supervision. The results of the theoretical model suggest that even with an internationally uniform risk-based capital requirement, it is unreasonable to expect banks in different countries to hold similar capital ratios. This occurs, in part, because regulators have discretion in how they apply the risk-based capital standards. Furthermore, the results suggest that a necessary condition for banks to exhibit similar capital ratios is that uniform capital requirements must be accompanied by a uniform stringency and application of regulatory supervision.
\end{abstract}

Keywords: international harmonization of capital requirements, 1988 and revised Basel Accords, risk-based capital ratio, bank supervision.

JEL Classification: G28, G21.

Received on: $30^{\text {th }}$ of January, 2017.

Accepted on: $9^{\text {th }}$ of March, 2017.

\section{Introduction}

In recent decades, bank regulators in various countries have devoted considerable effort to developing internationally agreed upon bank regulatory capital standards (i.e., the Basel Accords). In fact, some experts contend that over the last few decades, regulatory capital standards have become the primary tool used by regulators to try to ensure the safety and soundness of the banking system (Gup, 2004a). The original Basel Accord (Basel I) was formally agreed to in 1988, with more recent versions of the Accord (Basel II, 2.5 and III) being developed since the late 1990s. The primary purpose of the 1988 Accord was to develop regulatory capital standards that were sensitive to differences in credit risk across banks and to make capital requirements more uniform internationally (Office of the Comptroller of the Currency, 1989). The attention to the international harmonization of regulatory capital standards was a recognition on the part of regulators as to the international nature of modern financial markets, as well as an acknowledgement that lower capital requirements in some countries may confer to banks in those countries advantages in funding and lending markets (Gup, 2004b).

\footnotetext{
(C) Kevin T. Jacques, 2017.

Kevin T. Jacques, Ph.D., Boynton D. Murch Chair in Finance, Baldwin Wallace University, Former senior economist, Office of the Comptroller of the Currency, U.S. Department of the Treasury, Washington, D.C., USA.

An earlier version of this paper entitled "Bank Capital Structure and International Harmonization: The Basel Accord or Others Factors?" was presented at the Office of Financial Research, U.S. Department of the Treasury, Washington, D.C. The author thanks participants at that
} seminar, as well as Benton Gup, for their comments.

This is an Open Access article, distributed under the terms of the Creative Commons Attribution-NonCommercial 4.0 International license, which permits re-use, distribution, and reproduction, provided the materials aren't used for commercial purposes and the original work is properly cited.
With the advent of internationally uniform riskbased capital standards, the belief was that similar banking organizations, regardless of host country, would hold similar capital ratios. To see this, note that in a Modigliani-Miller world, a bank's use of deposit versus equity financing should be irrelevant. But regulatory capital standards constitute a departure from the Modigliani-Miller world, as capital is expensive. Therefore, bank managers want to hold less capital than is required by regulators with bank capital ratios tending to be determined by regulatory capital standards (Mishkin, 1995). This suggests that if regulators establish a uniform minimum regulatory capital standard that applies to all banks, such as Basel I, then, consistent with the goals of the 1988 Accord, we should expect banks to exhibit similar capital ratios. This belief in uniformity continues to exist in more recent versions of the Basel Accord, although recent releases by the Basel Committee (2013) now also stress the "comparability" of riskweighted assets. Furthermore, if the cost of violating regulatory capital standards is significant, then, banks may choose to hold a buffer stock of capital. But the existence of a buffer stock does not preclude the possibility that with uniform regulatory capital requirements, banks will hold similar capital ratios.

Although over 100 countries adopted the 1988 standards, research by Scott and Iwahara (1994) and Wagster (1996) suggests that an international equality of capital ratios did not prove to be true. And while much of the early research on risk-based capital noted the impact of the standards on capital ratios (Jacques and Nigro, 1997; Jackson et al., 1999; Rime, 2001) across countries, Gropp and Heider (2010) found that the capital ratios in 200 banks from the United States 
and European Union exhibited significant differences over the 1991 to 2004 period. On the question of why there exists such variation, Brewer et al. (2008) note that there is surprisingly little research.

More recently, the Basel Committee has undertaken innovations in regulatory capital standards, which appear to move away from the international harmonization of capital requirements (Gup, 2005). The goal of more recent versions of the Accord is to develop capital standards that are more sensitive to differences in risk and, as a result, reduce opportunities for regulatory capital arbitrage (Ferguson, 2000). In addition, these revised regulatory capital requirements (Pillar 1) are supplemented by enhanced supervision (Pillar 2) and disclosure requirements (Pillar 3). But Federal Financial Analytics (2012) notes that a number of developments regarding recent versions of the Basel Accord undermine the harmonization of capital standards.

Why does it matter? First, capital ratios signal the degree of leverage employed by banks. Recognizing that capital serves as a buffer to cushion against unexpected losses, a uniform minimum regulatory capital requirement represents an attempt by regulators to provide an internationally agreed upon floor of capital. And as noted by Berger et al. (1995), a higher capital ratio implies a lower likelihood of financial distress. Second, the design of regulatory capital standards is important, as regulators seek to promote competition in financial intermediation (Fisher, 2003), without being the source of competitive inequality or systemic risk (Federal Financial Analytics, 2012). Finally, given that regulators continue to talk of the "comparability of risk-weighted capital ratios", the design of prudential regulation and supervision of banks continues to be an important issue.

This study develops a one-period theoretical model to examine the relationship between uniform international regulatory capital standards, bank supervision, and bank capital ratios. More specifically, this paper contributes to the literature in a number of ways. First, this study examines the fundamental question of whether, given a uniform regulatory capital standard that applies to all banks, regulators should expect banks in different countries to hold similar capital ratios. Specifically, when banks operate in an environment where regulatory capital standards are uniform across countries, is it realistic to expect banks to hold similar capital ratios? While existing studies point to a host of macroeconomic, country-specific, and bank-specific factors that influence bank capital ratios, this study examines the level playing field argument in light of the stringency of bank supervision and the uniformity of regulatory capital standards. A second contribution of this study is that many existing theoretical studies of bank capital ratios require banks to be undercapitalized in order for regulatory capital requirements to influence bank balance sheets and capital ratios. This paper allows bank capital ratios to be influenced by minimum capital requirements, yet, recognizes the fact that most banks meet or exceed the minimum risk-based capital requirement. Finally, as noted by Marques Pereira and Saito (2015), few studies examine the interaction between regulatory capital requirements, bank supervision and bank capital ratios. This paper examines the relationship between these regulatory instruments and how they influence bank capital ratios.

\section{Model specification}

To investigate the issue of how uniform risk-based capital standards influence banks' capital ratios, a oneperiod theoretical model is developed. For simplicity, it is assumed that a representative bank's balance sheet contains three types of assets. One is commercial loans, $L$, that are considered risky assets, as they entail the possibility of default. Similar to Peek and Rosengren (1995), the bank competes in an imperfectly competitive lending market such that:

$L=d_{0}-d_{1}\left(r_{L}-\overline{r_{L}}\right)$,

where $r_{L}$ is the interest rate charged by the bank on a loan and $\overline{r_{L}}$ is the average interest rate charged by all banks in the loan market. Given the nature of the lending market, the bank's loans are influenced by the interest rate it offers commercial borrowers relative to the average rate in the market. A priori, $d_{0}$ and $d_{1}$ are positive with $d_{1}$ being larger, the more competitive the lending market.

The second asset is a government-issued security, $S$, that is considered credit risk free. The interest rate on the government security equals $r_{S}$ and while the rate may change over time, it is assumed that $\overline{r_{L}}>r_{S}$. Finally, the bank holds reserves, $\mathrm{R}$, with the reserve ratio $\alpha$ being set against transactions deposits (D) by the central bank. Thus:

$$
R \geq \alpha \mathrm{D} \text {. }
$$

It is assumed that the bank holds no excess reserves.

With regard to transactions deposits, these liabilities can be thought of as demand deposits with an interest rate equal to zero. An infinite supply of deposits is not an unreasonable assumption given, that deposits are assumed fully insured. However, the taking of transactions deposits by the bank brings with it the possibility of random depositor withdrawals and, assuming loans to be an illiquid asset, the bank holds a buffer stock of securities to guard against the possibility of needing to liquidate loans to meet depositor withdrawals. Following Stein (1998), this precautionary demand for securities assumes securities to be a fixed proportion (h) of transactions deposits. The liquidity constraint can be noted as: 
$\mathrm{S} \geq \mathrm{hD}-\alpha \mathrm{D}$.

In addition, the bank also funds assets using capital. With regard to capital, it is assumed that regulators impose on the bank a risk-based capital requirement that requires the bank to hold capital commensurate with the bank's perceived level of credit risk. Specifically, regulators specify the risk-based capital requirement such that:

$$
K \geq \theta\left(w_{L} L+w_{S} S+w_{R} R\right),
$$

where $w_{L}, w_{S}$, and $w_{R}$ are the risk weights corresponding to commercial loans, government securities, and reserves, respectively, and $\theta$ is the minimum risk-based capital requirement set at 8 percent under the Basel standards ${ }^{1}$. Under the Basel Accords, $w_{S}$ and $w_{R}$ equal 0 . More importantly, the regulatory capital standards are initially assumed to be uniform and known to all banks regardless of size of the bank, quality of risk management, or home country. In this theoretical model, uniformity is meant to imply that all banks are subject to the same riskbased capital standard. Thus, $\theta, w_{L}, w_{S}$, and $w_{R}$ are initially assumed to be the same across all banks.

Given equation (4), the bank also faces costs associated with the regulatory capital requirement. The risk-based capital standards mandate the minimum amount of capital the bank must hold against it's assets, and if the bank violates the minimum requirements it faces a number of potential costs including mandated increases in capital and the possibility of closure by the home country banking regulator. But contrary to the assumption made in much of the current research, even a bank that formally meets the minimum risk-based capital standards faces costs associated with regulation and supervision (Furfine, 2001). For example, in the United States, bank regulators may issue memorandums of understanding or cease and desist orders against banks in cases where the regulators deem the bank to be lacking sufficient capital, even if the bank formally meets the 8 percent minimum requirement. Furthermore, it can be argued that a bank whose risk-based capital ratio is closer to the regulatory minimum faces higher costs than a bank with a risk-based capital ratio that significantly exceeds the minimum requirements. Such a relationship can be noted by the fact that the authority for early intervention and corrective action emanates from powers granted to regulators by law, or more recently, by the Pillar 2 standards of the revised Accords, which state that regulators should "seek to intervene at an early stage to prevent capital from falling below the minimum levels required" (Basel Committee, 2004).

\footnotetext{
${ }^{1}$ Under the 1988 Basel Accord, all business loans were set such that $\mathrm{w}_{\mathrm{L}}$ $=1.00$ or 100 percent. Under Basel II, 2.5 and III, the Standardized Approach allows $\mathrm{w}_{\mathrm{L}}$ to differ depending on the credit risk of the loan.
}

Besides regulatory capital requirements, regulators also have at their disposal supervisory powers. These may take a number of different forms including enhanced supervisory monitoring or more detailed bank examinations. Unlike Shehzard and De Haan (2015), this study assumes all regulators to have the same supervisory powers, the only difference being the stringency with which these powers are applied. The existence of supervisory oversight by regulators adds to the bank's total cost of regulation and supervision, as more stringent supervision requires bank management to devote greater resources toward gathering information, interacting with regulators, and satisfying regulatory concerns. As such, supervision imposes real costs on the bank and its shareholders. Furthermore, the nature of the bank supervisory process allows for the possibility that regulators impose different levels of supervisory oversight, and, hence, different costs, on a bank even if the bank exhibits a risk-based capital ratio similar to other banks. This is not particularly surprising, as capital is but one measure regulators use to assess the safety and soundness of banks ${ }^{2}$.

Given that capital requirements and supervision impose costs on banks, the total cost of regulation and supervision a bank faces can be written as follows:

$C_{R}=\gamma\left(n_{0}-n_{1} \ln \left(K-\theta w_{L} L\right)\right)$.

The cost function is similar in nature to that employed by Furfine (2001) and is modeled as a negativelysloped convex function in $\mathrm{K}$ with the bank's risk-based capital requirement equal to $\theta w_{L} L$ and the stringency of supervision imposed by regulators modeled as $\gamma$. Both $\mathrm{n}_{0}$ and $\mathrm{n}_{1}$ are assumed to be positive where $\ln$ signifies the natural $\log$. As a result, if the bank increases its holdings of capital relative to the regulatory required minimum, its cost of regulation and supervision will decrease. Alternatively, given the convexity of equation (5), the total cost of regulation and supervision not only increases as bank capital decreases, but also it does so at an increasing rate. In that sense, consistent with Klomp and De Haan (2012), capital regulations and bank supervision would be expected to have a greater impact on banks with smaller buffer stocks of capital.

Under these conditions, the bank seeks to maximize:

Maximize: $r_{L} L+r_{S} S-C_{R}$,

subject to: $L+S=D+K$,

$S \geq h D-\alpha D$,

where equation (7) is the standard balance sheet condition and equation (8) captures the liquidity condition.

\footnotetext{
${ }^{2}$ For example, in the United States, banks are given CAMELS scores by regulators, where CAMELS stands for capital, asset quality, management, earnings, liquidity, and sensitivity to risk.
} 


\section{Results}

Using equation (1) to eliminate $r_{L}$ and substituting equations (2) through (5) into equation
(6), the

constrained

problem becomes:

Maximize:

$$
\frac{\left(d_{0}+d_{1} \overline{r_{L}}-L\right)}{d_{1}} L+r_{S} S-\gamma\left(n_{0}-n_{1} \ln \left(K-\theta w_{L} L\right)\right)+\lambda_{1}(L+S+\alpha D-D-K)+\lambda_{2}(S-h D+\alpha D),
$$

with $\lambda_{1}$ being associated with the balance sheet condition and $\lambda_{2}$ being associated with the liquidity constraint. Solving for the optimal levels from the first-order conditions in the model yields:

$$
\begin{aligned}
L^{*} & =\frac{-(1-h)\left(d_{0}+d_{1} \overline{r_{L}}\right)+d_{1}(\alpha-h)\left(1-\theta w_{L}\right) r_{S}}{2(h-1)} \\
S^{*} & =\frac{-2 \gamma n_{1}(h-1)^{2}-(\alpha-h)\left(1-\theta w_{L}\right) r_{S}\left((1-h)\left(d_{0}+d_{1} \overline{r_{L}}\right)-d_{1}(\alpha-h)\left(1-\theta w_{L}\right) r_{S}\right)}{2(h-1)^{2} r_{S}} \\
\mathrm{R}^{*} & =\alpha \mathrm{D}^{*} \\
D^{*} & =\frac{2 \gamma(h-1)^{2} n_{1}+(\alpha-h)\left(1-\theta w_{L}\right) r_{S}\left((1-h)\left(d_{0}+d_{1} \overline{r_{L}}\right)+d_{1}(\alpha-h)\left(\theta w_{L}-1\right) r_{S}\right)}{2(\alpha-h)(h-1) r_{S}} \\
K^{*} & =\frac{2 \gamma(h-1)^{2} n_{1}-(\alpha-h) r_{S} \theta w_{L}\left((1-h)\left(d_{0}+d_{1} \overline{r_{L}}\right)-d_{1}(\alpha-h)\left(\theta w_{L}-1\right) r_{S}\right)}{2(\alpha-h)(h-1) r_{S}}
\end{aligned}
$$

Given these results, a bank's risk-weighted assets (RWA) equals:

$$
R W A^{*}=w_{L} L^{*}=\frac{-w_{L}(1-h)\left(d_{0}+d_{1} \overline{r_{L}}\right)+d_{1}(\alpha-h)\left(1-\theta w_{L}\right) r_{S}}{2(h-1)},
$$

while it's bank's risk-based capital ratio (RBCR) equals:

$$
R B C R^{*}=\frac{2 m_{1}(h-1)^{2}-(\alpha-h) \theta w_{L} r_{S}\left((1-h)\left(d_{0}+d_{1} \bar{r}_{L}\right)+d_{1}(\alpha-h)\left(\theta w_{L}-1\right) r_{S}\right)}{(\alpha-h) w_{L} r_{S}\left((h-1)\left(d_{0}+d_{1} \bar{r}_{L}\right)-d_{1}(\alpha-h)\left(\theta w_{L}-1\right) r_{S}\right)} .
$$

The results suggest that a bank's optimal level of riskweighted assets and risk-based capital ratio are a complex interaction of a host of factors including financial regulatory instruments, structural characteristics of the lending market, the precautionary demand for securities, interest rates, and the reserve requirement ratio. Given the results of equations (15) and (16), the non-regulatory factors may cause bank capital ratios to vary across banks. It is also trivial to see that if the regulatory and non-regulatory factors are the same both within and across countries, then banks will exhibit the same risk-based capital ratios. For the sake of analysis, these non-regulatory factors are assumed to be the same both within and across countries. While this is obviously an oversimplification, this assumption allows us to better understand the impact of uniform regulatory capital standards. This assumption also reflects the fact that while these variables may influence bank balance sheet and capital decisions, they are generally exogenous to regulators ${ }^{1}$.

\footnotetext{
${ }^{1}$ Exceptions may exist, for example, in countries such as Brazil and Italy the central bank also has supervisory authority over banks.
}

2.1. Uniformity in regulatory capital standards and supervision. In the context of the model, bank regulators have at their disposal three regulatory instruments that can potentially impact the risk-based capital ratio a bank chooses to hold: (1) the minimum risk-based capital ratio, $\theta ;(2)$ the risk-weight assigned to the risky asset, $w_{L}$; and, (3) the stringency of supervision, $\gamma$. In the sections that follow, the first-order conditions from the theoretical model are examined in order to assess the impact of uniformity in regulatory capital standards and bank supervision.

2.2. National discretion in the minimum riskbased capital ratio. As discussed earlier, the uniformity of the risk-based capital standards is noted by the fact that the internationally-agreed upon riskbased capital standards set $\theta$ at 8 percent, with the risk weights $w_{L}, w_{S}$, and $w_{R}$ also assumed to uniform across banks regardless of country. One possible reason for variation in bank capital ratios is that while the risk-based capital standards are generally uniform in nature, they do grant national discretion to regulators (Basel Committee, 2014b). For example, in the United States, regulators have always stressed that the 8 percent risk-based capital ratio is 
considered a minimum and that regulators may require additional capital if warranted (Office of the Comptroller of the Currency, 1989). Furthermore, in Brazil, the minimum risk-based capital ratio was raised from 8 percent to 11 percent as a result of the Asian crisis in 1997 (Marques Pereira and Saito, 2015), while Gup (2005) notes that regulators in other countries including Israel and Venezuela have chosen to set $\theta$ above 8 percent.

Obviously, raising the minimum risk-based ratio above 8 percent raises the question of what regulators mean by the "uniformity". But just because regulators use national discretion to require capital above 8 percent does not necessarily preclude the possibility that bank capital ratios both within and across countries are the same. To see this note, in the theoretical model delineated in equations (1) (8), the representative bank is already assumed to have capital in excess of the 8 percent regulatory minimum. As a result, the bank has options in how it responds to an increase in the minimum regulato- ry capital ratio. One possibility is that the bank reduces the size of its capital buffer $\left(K^{*}-\theta w_{L} L^{*}\right)$, thereby allowing the bank to maintain its current asset mix. Because the bank does not alter its riskbased capital ratio in response to an increase in $\theta$, capital ratios across bank balance sheets should not be influenced by the increase in the minimum regulatory capital ratio.

Alternatively, the bank may respond to an increase in $\theta$ by increasing its risk-based capital ratio. This can be accomplished: 1) by increasing capital; 2) by reducing risk-weighted assets; or 3) some combination of the two. To see why this may occur, note that an increase in $\theta$ increases the total cost of regulation and supervision to the bank. If $\theta$ is viewed as a regulatory tax on risky assets, one which imposes costs on the bank and increases $C_{R}$, then, the bank's holdings of risky assets and its risk-based capital ratio may no longer be optimal. To see the impact of a country's regulators raising the minimum risk-based capital ratio:

$$
\begin{aligned}
& \frac{\partial K}{\partial \theta}=\frac{w_{L}\left((h-1)\left(d_{0}+d_{1} \bar{r}_{L}\right)-d_{1}(\alpha-h)\left(2 \theta w_{L}-1\right) r_{S}\right)}{2(h-1)}>0, \\
& \frac{\partial R W A}{\partial \theta}=\frac{-d_{1}(\alpha-h) w_{L}^{2} r_{S}}{2(h-1)}<0, \\
& \frac{\partial R B C R}{\partial \theta}=\frac{d_{0}^{2}(h-1)^{2}+2 d_{0} d_{1}(h-1)\left((h-1) \bar{r}_{L}-(\alpha-h)\left(\theta w_{L}-1\right) r_{S}\right)}{\left((h-1)\left(d_{0}+d_{1} \bar{r}_{L}\right)-d_{1}(\alpha-h)\left(\theta w_{L}-1\right) r_{S}\right)^{2}}+ \\
& +\frac{d_{1}\left(2 \gamma(h-1)^{2} n_{1}+d_{1}\left((1-h) \bar{r}_{L}+(\alpha-h)\left(\theta w_{L}-1\right) r_{S}\right)^{2}\right)}{\left((h-1)\left(d_{0}+d_{1} \bar{r}_{L}\right)-d_{1}(\alpha-h)\left(\theta w_{L}-1\right) r_{S}\right)^{2}}>0 .
\end{aligned}
$$

Assuming $w_{L}$ equals 100 percent, $\left(\theta w_{L}-1\right)<0$. Furthermore, a bank is assumed to have a precautionary demand for securities that exceeds the reserve requirement ratio $(\alpha<\mathrm{h}<1)$. In some countries, such as Canada, this is obvious, as the reserve requirement ratio in those countries equals zero, while in countries such as India, the central bank sets a minimum statutory liquidity ratio which is currently greater than the reserve requirement ratio ${ }^{1}$.

The results of equations (17) and (18) show that grouth in the minimum risk-based capital ratio results in the bank increasing their capital and reducing their risk-weighted assets, even though the bank may already meet the higher minimum capital ratio. As a result, and seen in equation (19), the bank's risk-based capital ratio increases. The increase in $\theta$ raises both the actual and relative cost of holding risky assets, as an increase in $\theta$ has no direct impact on the cost of holding securities. Furthermore, the

\footnotetext{
${ }^{1}$ In India, the statutory liquidity ratio is currently set at 22 percent and the reserve requirement ratio equals 4 percent. See Reserve Bank of India.
}

increase in regulatory costs is not uniform, as greater costs are incurred in cases where the bank is near the regulatory minimum. To see this note:

$$
\frac{\partial C_{R}}{\partial \theta}=\frac{m_{1} w_{L} L}{K-\theta w_{L} L}>0
$$

Given that $\left(K-\theta w_{L} L\right)$ is the bank's capital buffer, the larger the buffer the smaller the impact an increase in the minimum risk-based capital ratio has on the cost of regulation and supervision. As a result, the bank responds to the increase in part not only by reducing its holding of the risky asset, but also by increasing its level of capital. Despite the theoretical nature of the model, this result is consistent with the argument from Milne and Whalley (1999) that during a period of increased capital requirements, banks become more risk averse leading to a reduction in the risky asset, as well as empirical findings about bank balance sheet changes by Jacques and Nigro (1997). More importantly, the results of this section suggest that changes in the minimum risk-based capital ratio result in banks altering both their risk- 
weighted assets and risk-based capital ratios, a result that is inconsistent with banks exhibiting similar capital ratios.

2.3. National discretion in setting risk weights on risky assets. In addition to the discretion to set the minimum risk-based capital ratio, the Basel Accords also grant to regulators in different jurisdictions the discretion to set the risk weight on various assets at levels different from those that exist under the uniform rules. The Basel Committee recognizes that the "structure and development of financial systems warrant different approaches" (Basel Committee, 2014a). Futhermore, the Basel Committee argues that such discretion should level the playing field, thereby improving comparability, by recognizing that while the assets in question may be the same, the risk associated with that assets may differ across countries (Basel Committee, 2013). The question, then, becomes, given the possibility of national discretion in risk weights, whether it is reasonable to expect risk-based capital ratios to be the same. While national discretion may violate the idea of uniformity in regulatory capital standards, it does not automatically mean that capital ratios won't be similar. As discussed in the previous section, if banks maintain a buffer stock of capital, then, the bank may simply choose to operate with a smaller buffer. Alternatively, the bank may choose to adjust either its capital or riskweighted assets or both in response to a change in the risk weight. To see the impact in the model under this scenario, assume that $\theta$ equals 8 percent, but that regulators, using national discretion, increase $w_{L}$. Thus:

$$
\begin{aligned}
& \frac{\partial L}{\partial w_{L}}=\frac{d_{1}(h-\alpha) r_{S}}{2(h-1)}<0, \\
& \frac{\partial R W A}{\partial w_{L}}=\frac{d_{0}(h-1)+d_{1}\left((h-1) \bar{r}_{L}-(\alpha-h)\left(2 \theta w_{L}-1\right) r_{S}\right)}{2(h-1)}>0, \\
& \frac{\partial K}{\partial w_{L}}=\frac{\theta\left(d_{0}(h-1)+d_{1}\left((h-1) \bar{r}_{L}-(\alpha-h)\left(2 \theta w_{L}-1\right) r_{S}\right)\right)}{2(h-1)}>0, \\
& \frac{\partial R B C R}{\partial w_{L}}=\frac{2 \gamma(h-1)^{2} n_{1}\left(d_{0}(1-h)+d_{1}\left((1-h) \bar{r}_{L}+(\alpha-h)\left(2 \theta w_{L}-1\right) r_{S}\right)\right.}{(\alpha-h) w_{L}^{2} r_{S}\left(d_{0}(1-h)+d_{1}\left((1-h) \bar{r}_{L}+(\alpha-h) r_{S}\left(\theta w_{L}-1\right)\right)\right)^{2}}<0 .
\end{aligned}
$$

From equation (21), the bank decreases its holdings of loans, as both the absolute and relative cost of holding loans has increased. With an increase in $w_{L}$ and a decrease in $L$, equation (22) shows that risk-weighted assets increase, as the increased risk weight on loans more than offsets the decreased holdings of the asset. As a result, total risk-weighted assets increase with a corresponding growth in capital. Given these results, the bank's risk-based capital ratio decreases. This result is shown in equation (24). This occurs because the increase in capital corresponding to the minimum riskbased capital requirement (equation (23)) is smaller than the bank's existing capital ratio. More importantly, the results of this section provide a theoretical analysis to show that when regulators change the risk weights assigned to risky assets, a bank's total riskweighted assets and risk-based capital ratio will deviate from that which would be expected under a uniform rule.

2.4. Differences in bank supervision. A third tool available to regulators is the stringency of supervision and regulatory enforcement, signified in the model by the term $\gamma$. To see the impact of the stringency of supervision in this model, assume that the risk-based capital standards are uniform across countries with $\theta$ equal to 8 percent and $w_{L}=1.0$. As noted earlier, bank regulators may have different levels of supervisory oversight even for banks with the same risk-based capital ratio. This is consistent with research by Barth et al. (2004), which concludes that regulators in different countries impose different levels of supervision. Thus, despite efforts by the Basel Committee to strengthen supervisory oversight in more recent versions of the Basel Accord (Pillar 2), levels of supervision are likely to continue to differ both across countries (Shadow Financial Regulatory Committee, 2001).

A priori, it is not apparent how differences in the stringency of bank supervision impact bank capital ratios. Empirical research by Aggarwal and Jacques (2001) suggests that greater supervisory power, in the form of the prompt corrective action provisions of FDICIA in the United States, resulted in banks increasing their risk-based capital ratios, while Fonseca et al. (2010) found that regulatory supervision reduces market discipline and decreases the economic incentive to hold capital.

From the theoretical model, the application of supervisory oversight by regulators results in:

$$
\begin{aligned}
& \frac{\partial K}{\partial \gamma}=\frac{(h-1) n_{1}}{(\alpha-h) r_{S}}>0, \\
& \frac{\partial R W A}{\partial \gamma}=0,
\end{aligned}
$$




$$
\frac{\partial R B C R}{\partial \gamma}=\frac{-2(h-1)^{2} n_{1}}{(\alpha-h) w_{L} r_{S}\left((1-h)\left(d_{0}+d_{1} \bar{r}_{L}\right)+d_{1}(\alpha-h)\left(\theta w_{L}-1\right) r_{S}\right.}>0 .
$$

Maintaining the assumptions $\alpha<\mathrm{h}<1$ and $\left(\theta w_{\mathrm{L}}-1\right)<$ 0 , equation (27) demonstrates that if there exists heterogeneity in the stringency of supervision across countries, risk-based capital ratios will vary across banks with greater levels of supervision being associated with banks exhibiting higher risk-based capital ratios.

Equations (25) and (26) further highlight how this process happens. Higher levels of $\gamma$ imply that regulators are imposing more stringent levels of supervision on banks, thereby increasing CR. As a result, the bank maintains its risk-weighted assets while increasing capital. This is consistent with findings by Duran and Lozano-Vivas (2015) that supervision is effective in disincentivizing risk shifting in European banks that possess significant capital buffers. The result occurs, because, unlike an increase in the minimum capital ratio, an increase in the stringency of supervision does not increase the direct or indirect cost of holding the risky asset. Rather, an increase in $\gamma$ raises the total cost of regulation and supervision the bank faces and the bank responds by increasing capital. The increased holdings of capital, given that risk-weighted assets are unchanged, raise the bank's risk-based capital ratio, while allowing the bank to maintain its existing asset allocation. Given this result, differences in the stringency of regulatory supervision across and within countries is consistent with variation in risk-based capital ratios. Furthermore, the theoretical nature of the model helps to explain why and how differences in supervision lead to differences in bank capital ratios.

\section{The interaction between capital regulation and supervision}

In the context of ensuring the safety and soundness of banks, the importance of supervision, and how it interacts with regulatory capital standards cannot be stressed enough. If supervision is sufficiently lax, then the bank's optimal level of capital relative to the minimum capital requirement decreases, thereby reducing, the bank's capital buffer and ultimately resulting in the risk-based capital ratio converging to the regulatory minimum. To see this, note the size of the capital buffer in equation (28) and the limit of that buffer as the stringency of bank supervision is reduced in equation (29):

$$
K^{*}-\theta w_{L} L^{*}=\frac{-2 \gamma(h-1)^{2} n_{1}}{(\alpha-h) w_{L} r_{S}\left((1-h)\left(d_{0}+d_{1} \bar{r}_{L}\right)+d_{1}(\alpha-h)\left(\theta w_{L}-1\right) r_{S}\right)},
$$

$$
\lim \left(K^{*}-\theta w_{L} L^{*}\right)_{\gamma \rightarrow 0}=0 .
$$

Given that capital functions as a buffer to absorb unexpected losses, and regulators have explicitly stated that banks should hold capital in excess of the regulatory minimum, this result has potentially important implications for the safety and soundness of banks. Equation (29) reveals that as the stringency of supervisory oversight decreases, capital decreases relative to the minimum capital requirement. This occurs despite the fact that the $\theta$ equals 8 percent and the fact that the decrease in the capital cushion results an increased in CR. Thus, uniformity in bank regulatory capital standards is not sufficient, in and of itself, to ensure that banks hold similar capital ratios. Rather, even if all non-regulatory factors are the same, the uniformity of minimum capital requirements must be matched, at a minimum, by uniformity in the stringency of bank supervision. And while the Basel Committee has published a "best practices" document for supervision (Basel Committee, 2012), as Barth et al. (2014) note, the attainment of uniformity in supervision levels is likely an unrealistic goal, as supervisors disagree about how best to supervise banks. Rather, cross country differences in institutional, political, and cultural factors likely result in regulators designing supervisory and regulatory enforcement systems more uniquely tailored to their banks and financial systems. In addition, supervision remains vitally important in order to minimize risk weight manipulation (Mariathasan and Merrouche, 2014).

\section{Conclusion}

In recent decades, bank regulators in various countries have devoted considerable effort to developing internationally agreed upon bank regulatory capital standards. While more recent changes were designed to make capital requirements more sensitive to differences in risk, the Basel Committee continues to stress the uniformity of regulatory capital requirements. But despite the uniform nature of the standards, the capital ratios of banks across countries exhibit significant differences.

This paper uses a one-period theoretical model to ask the question of given uniformity in regulatory capital standards, is it reasonable to expect banks in different countries to exhibit similar capital ratios? Consistent with existing empirical research, the theoretical results suggest that even with a uniform risk-based capital rule, it is unreasonable to expect banks to exhibit similar capital ratios. This occurs for three reasons. First, the risk-based capital standards provide regulators in different countries discretion to set the minimum capi- 
tal requirement higher than 8 percent. The results presented herein suggest that banks in these countries will tend to increase their risk-based capital ratios in part by reducing their risk-weighted assets. Second, the Basel Accords allow regulators to alter the risk weights on selected risky assets. The results in this study suggest that the use of national discretion in this case causes banks facing higher risk weights to increase their riskweighted assets and reduce their risk-based capital ratios relative to banks where risk weights were not raised. Finally, despite the efforts of regulators to make bank supervision more consistent via Pillar 2 of the revised Accords, bank supervision remains disparate across countries. As a result, banks facing different levels of supervision would be expected to exhibit different capital ratios. Thus, commonality in rules for capital should not be interpreted to suggest that banks in different countries will hold similar capital ratios.
Given that regulators should not expect banks to hold similar capital ratios, the question becomes what should be the goal of risk-based capital regulation?

One goal could be to make regulatory capital standards as accurate as possible in hopes of reducing regulatory capital arbitrage. Others have argued that disparities in capital ratios are inevitable. Thus, the best result may be to write riskbased capital standards as a guide to best practices (Federal Financial Analytics, 2012). And finally, some have argued that simple risk-based capital rules, such as the 1988 Accord, combined with a single leverage ratio are a more effective approach (Shadow Financial Regulatory Committee, 2013). While such an approach will not eliminate regulatory capital arbitrage, it may help to ensure that banks maintain adequate capital.

\section{References}

1. Aggarwal, R., Jacques, K. T. (2001). The impact of FDICIA and prompt corrective action on bank capital and risk: estimates using a simultaneous equations model. Journal of Banking and Finance, 25, 1139-1160.

2. Barth, J. R., Gan, J., Nolle, D. E. (2004). Global trends in the bank regulatory and supervisory environments. In Reforms and Innovations in Bank Management, Duk-Hoon Lee and Gill-Chin Lim, editors, Seoul, Korea, Nanam Publishing House, 49-93.

3. Barth, J. R., Nolle, D. E. (2014). Regulation and supervision of the biggest banks by the biggest countries. Milken Institute Research Report, January 22, 2014.

4. Basel Committee on Banking Supervision. (2004). Basel II: International Convergence of Capital Measurement and Capital Standards: A Revised Framework.

5. Basel Committee on Banking Supervision. (2012). Core Principles for Effective Banking Supervision.

6. Basel Committee on Banking Supervision. (2013). The regulatory framework: balancing risk sensitivity, simplicity, and comparability. Discussion paper.

7. Basel Committee on Banking Supervision. (2014a). Capital floors: the design of a framework on standardized approaches - consultative document.

8. Basel Committee on Banking Supervision. (2014b). Basel capital framework national discretions.

9. Basel Committee on Banking Supervision. (2014c). Reducing excessive variability in banks' regulatory capital ratios: A report to the G20.

10. Berger, A. N., Herring, R. J., Szego, G. P. (1995). The role of capital in financial institutions. Journal of Banking and Finance, 19, 393-430.

11. Brewer, E., Kaufman, G. G., Wall, L. D. (2008). Bank capital ratios across countries: why do they vary? Journal of Financial Services Research, 34, 177-201.

12. Duran, M. A., Lozano-Vivas, A. (2015). Moral hazard and the financial structure of banks. Journal of International Financial Markets, Institutions \& Money, 34, 28-40.

13. Federal Financial Analytics, Inc. (2012). Basel's burst bubble: how Basel has broken apart and what should be done to fix bank regulation, August 27.

14. Ferguson, R. W. (2003). Testimony of Vice Chairman Roger W. Ferguson, Jr., Committee on Banking, Housing and Urban Affairs, U.S. Senate, June 18, 2003.

15. Fisher, P. (2003). Keynote address: The need to reduce regulatory capital arbitrage. Brooklyn Journal of International Law, 28, 455-460.

16. Fonseca, A. R., Gonzalez, F. (2010). How bank capital buffers vary across countries: the influence of cost of deposits, market power, and bank regulation. Journal of Banking and Finance, 34, 892-902.

17. Furfine, C. (2001). Bank portfolio allocation: the impact of capital requirements, regulatory monitoring, and economic conditions. Journal of Financial Services Research, 20, 33-56.

18. Gropp, R., Heider, F. (2010). The determinants of bank capital structure. Review of Finance, 14, 587-622.

19. Gup, B. (2004a). The inadequacy of capital adequacy policies. The New Basel Capital Accord. Benton Gup ed., Thomson Publishing, 177-216.

20. Gup, B. (2004b). Basel II creates an uneven playing field. The New Basel Capital Accord, Benton Gup ed., Thomson Publishing, 53-66.

21. Gup, B. (2005). Insights from a global survey on bank capital. Capital Markets, Globalization and Economic Development, Benton Gup ed., Springer Publishing, 1-8. 
22. Jackson, P, Furfine C., Groeneveld H., Hancock D., Jones D., Perraudin W. (1999). Capital requirements and bank behavior: the impact of the basle accord. Basle Committee on Banking Supervision Working Paper no. 1.

23. Jacques, K. T., Nigro, P. (1997). Risk-based capital, portfolio risk, and bank capital: a simultaneous equations approach. Journal of Economics and Business, 49, 533-547.

24. Klomp, J., De Haan, J. (2012). Banking risk and regulation: does one size fit all? Journal of Banking and Finance, 36, 3197-3212.

25. Mariathasan, M., Merrouche, O. (2014). The manipulation of risk weights. Journal of Financial Intermediation, 23, 300-321.

26. Marques Pereira, J. A. C., Saito, R. (2015). How banks respond to central bank supervision: Evidence from Brazil. Journal of Financial Stability, 19, 22-30.

27. Milne, A., Whalley, A. E. (1999). Bank capital and risk-taking. Bank of England Working Paper Series, no. 90.

28. Mishkin, F. (1995). The economics of money, banking and financial markets. $4^{\text {th }}$ edition, Addison Wesley, New York, 268.

29. Office of the Comptroller of the Currency. (1989). Risk-based capital guidelines; final rule. Federal Register, January $27,4167-4184$.

30. Peek, J., Rosengren, E. (1995). The capital crunch: neither a borrower nor a lender be. Journal of Money, Credit and Banking, 27, 625-638.

31. Reserve Bank of India. Retrieved from https://rbi.org.in/home.aspx

32. Rime, B. (2001). Capital requirements and bank behavior: empirical evidence for Switzerland. Journal of Banking and Finance, 25, 789-805.

33. Scott, H. S., Iwahara, S. (1994). In search of a level playing field: The implementation of the basle capital accord in Japan and the United States. The Group of Thirty Occasional Paper.

34. Shadow Financial Regulatory Committee. (2001). The Basel Committee's Revised Capital Accord Proposal. Statement Number 169.

35. Shadow Financial Regulatory Committee. (2013). Making bank capital requirements simpler, more comparable, \& more transparent. Statement number 343.

36. Shehzard, C. T., De Haan, J. (2015). Supervisory power and bank risk taking. Journal of International Financial Markets, Institutions \& Money, 39, 15-34.

37. Stein, J. C. (1998). An adverse-selection model of bank asset and liability management with implications for the transmission of monetary policy. RAND Journal of Economics, 29, 466-486.

38. Wagster, J. D. (1996). Impact of the 1988 basel accord on international banks. Journal of Finance, 51, $1321-1346$. 